\title{
The Student Youth with Predisposition to Deviant Behavior, Depending on the Field of Study \\ ${ }^{1}$ Yanna G. Garanina, ${ }^{2}$ Tatiana V. Artemyeva, \\ ${ }^{1,2}$ Kazan Federal University, PhD, Associate Professor, 18 Kremlevskaya St., Kazan, 420008, Republic of \\ Tatarstan, Russian Federation \\ Email: Tatyana.Artemeva@kpfu.ru
}

Received: 15th December 2017, Accepted: 20th December 2017, Published: 31st December 2017

\begin{abstract}
Normative systems of society do not stand still. With changing the norms, the attitude towards them also changes. The deviation from the norm is as natural as adherence to them. The most vulnerable group are the students whose system of views and principles is in the process of formation, and the system of values and norms that has not fixed yet cannot provide the necessary guidelines for behavior. The study attempted to study the dependence of proneness to violate social norms and rules by men and women with regard to the disciplines studied. The study was carried out using the methods by A.N. Orel "Diagnosis of Predisposition to Deviant Behavior".309 students (249 women, 60 men) took part in the study. The results of the study revealed that the difference in the tendency to deviate from the norms among the students of the same sex is that men pursuing the humanities, in contrast to men of natural science, are more prone to risk, they need thrilling experience. The comparison of men and women studying humanitarian disciplines showed that women are inclined to conflict with the generally accepted lifestyle and legal norms. Men have a proneness to an illusory and compensatory solution of personal problems, in addition, they are prone to various kinds of addictions. The results of the research can be of interest to the specialists working in the system of prevention of deviant behavior.
\end{abstract}

Keywords: Social Norms, Deviant Behavior, Students, Natural Science, Humanitarian Disciplines.

\section{Introduction}

In a continuously changing society, the lack of a stable regulatory system reduces the likelihood of people to choose a clear line of normative behavior, which naturally leads to the growth of various forms of deviant behavior. In these conditions, the most vulnerable group of the population is proved to be young people, due to their social and psychologicalage characteristics. Despite the fact that the issue of deviance is dealtwithby the works of domestic and foreign researchers, at the moment there is no single point of view about what "deviant behavior" is. According to Gilinsky, deviant behavior is understood as the act, the action of a person that does not correspond to the norms officially accepted or actually formed in a given society [1]. Rozhkov understands deviant behavior as deviation from the social and moral norms and the cultural values accepted in society, social environment, the community [2]. Kovalev defines deviant behavior as the behavior that deviates from the moral norms of a given society [3]. A number of authors (A. G. Abrumov, E. V. Zmanovskaya, I. S. Kon) differentiate deviant (deviant) and delinquent (criminal) behavior in their classifications (the term "delinguens" is an offence, a fault) [3]. Zmanovskaya defines delinquent behavior as actions of a concrete person that deviate from the laws established in the given society and at the given time, threaten the well-being of other people and criminal and are punishable in their extreme manifestations [4]. Dimov sees the line that separates norms from deviant in the destructive effects of negative phenomena, which is a real threat to a social survival of man [5].The work by Western researchers (Chan, H.C., Beauregard, E.) deals with psychopathological profiles and offers different approaches to the classification of criminals [6].Savina marks out the factors causing the delinquent behavior of students: academic failure, emotional immaturity, hyperactivity, communication disorders, loneliness, bad habits, social incompetence [7]. The study by Lopez reveals that the goals of social development and normative regulations are directly related to social adaptation [10].The results of Baier's research showed that psychological and moral pressure from the teacher is a negative factor causing deviant behavior of adolescents [8]. The article by Twine singles out three types of preactions of aggression and violence between the students of different age groups. Social aggression includes malicious insults, demonstrating power, modeling dominant behavior, in which the subjects try to protect their status or force out others [9].Aleksandrovichin his article regards the family as a factor that forms both social attitudes and antisocial behavior, since social attitudes of the person have a direct effect on asocial behavior [11].The results of Herndon's work showed the connection between the influence of peers and antisocial behavior. The influence of peers had an indirect and positive impact on the ability for mathematics, because it had a direct effect on school behavior and indirect influence on delay of satisfaction, deviant behavior had an indirect and negative impact on the ability for mathematics due to its direct effect on delayed satisfaction, aggressive 
behavior, psychoactive substance abuse and behavior in school [12].

So, despite the differences in interpretation, the authors' opinion coincides in the fact that the main criterion of deviant behavior is to be considered the violation of social norms accepted in society. This is the behavior that deviates from the norms of morality adopted in a given society at a certain level of social and cultural development, and which can lead to sanctions: isolation, punishment, treatment, conviction and other forms of censure of the offender.

\section{Materials and Methods}

\section{Research Method}

To study the dispositions of the subjects towards violation of social norms, we applied the methodsby

O.N. Orel"Diagnosis of Predisposition to Deviant
Behavior" (Kleiberg, 2007), which uses the following scales: proneness to capability of norms and rules; propensity to addictive behavior; predisposition to self-mutilation and selfdestruction; predisposition to aggression and violence; volitional control of emotional reactions; predisposition to delinquent behavior.

\section{Participants}

The study involved 309 students aged from 17 to 24 . Participation in the experiment was voluntary, free.

The female sample was 249 people, the male sample was 60. Two groups of disciplines studied by the subjects: humanitarian disciplines and natural science disciplines. Table 1 and Table 2 present full information about the participants in the experiment.

Table 1 Information about the Subjects

\begin{tabular}{|c|c|c|c|c|c|c|}
\hline Subjects & $\mathbf{N}$ & $\begin{array}{l}\text { Average } \\
\text { age }\end{array}$ & Min & Max & Me & SD \\
\hline Sample & 309 & 19.9 & 17 & 24 & 20 & 1.62 \\
\hline Women & 249 & 19.8 & 17 & 24 & 20 & 1.62 \\
\hline Men & 60 & 20.3 & 18 & 24 & 20 & 1.53 \\
\hline
\end{tabular}

Table 2 - Disciplines Studied by the Subjects

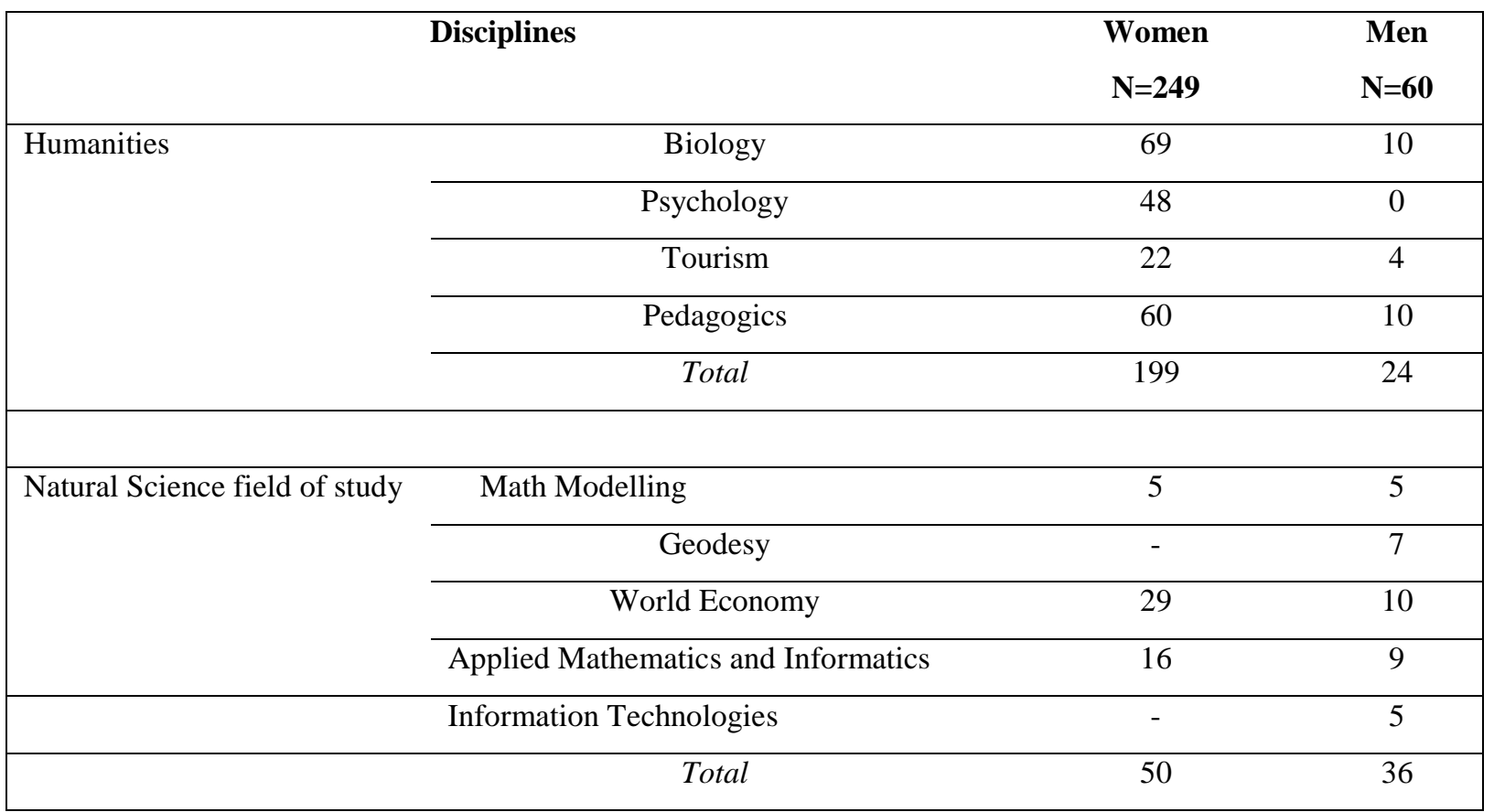

\section{Research Questions}

1. Are there the differences in demonstration of the forms of deviant behavior by the students of various areas of study?
2. There are gender-specific uses of humor: men are more likely to have an aggressive style of humor than women.

\section{Results}

It was revealed during the research that in the sample of men and women that specialize in human 
sciences, the highest average scores were obtained according to the scale "Predisposition to aggression and violence" $(\mathrm{M}=10.28$ for women and $\mathrm{M}=9.91$ for men). There were no statistically significant differences between the male and female samples from these scales.
Men studying the humanitarians proved to have two indicators higher: "Proneness to addictive behavior" $(p<.01)$, "Predisposition to self-mutilation and selfdestruction" $(p<.05)$. Women of the humanities had only one evaluation scale higher than men, namely, "Predisposition to delinquent behavior" $(\mathrm{p}<.05)$.

Table 3. Predisposition of the Subjects to Deviant Behavior in Women and Men Studying Humanitarian Disciplines

\begin{tabular}{|c|c|c|c|c|c|c|}
\hline \multirow[t]{2}{*}{ Subjects } & \multicolumn{2}{|c|}{$\begin{array}{l}\text { Men } \mathrm{H} \\
\qquad(\mathrm{n}=24)\end{array}$} & \multicolumn{2}{|c|}{$\begin{array}{l}\text { Women } \mathrm{H} \\
\qquad(\mathrm{n}=198)\end{array}$} & \multirow[t]{2}{*}{$\mathrm{t}(222)$} & \multirow[t]{2}{*}{$\mathrm{p}$} \\
\hline & M & SD & $\mathrm{M}$ & SD & & \\
\hline \multicolumn{7}{|l|}{ Scales } \\
\hline $\begin{array}{l}\text { Proneness to copability of norms and } \\
\text { rules }\end{array}$ & 7.25 & 3.02 & 7.75 & 2,06 & 1.07 & .283 \\
\hline Proneness to addictive behavior & 9.66 & 4.68 & 6.67 & 3.12 & 4.16 & $\mathrm{p}<.01$ \\
\hline $\begin{array}{l}\text { Predisposition to self-mutilation and self- } \\
\text { distruction }\end{array}$ & 9.62 & 3.64 & 8.03 & 3.78 & 1.95 & $\mathrm{p}<.05$ \\
\hline Predisposition to aggression and violence & 9.91 & 4.30 & 10.28 & 3.16 & .52 & .603 \\
\hline Volitional control of emotional reactions & 6.66 & 3.03 & 7.38 & 2.19 & 1.44 & .151 \\
\hline Disposition to delinquent behavior & 7.00 & 3.71 & 8.36 & 3.00 & 2.04 & $\mathrm{p}<.05$ \\
\hline
\end{tabular}

In the analyzed sample of women and men who pursue naturally scientific areas of study, the highest average scores were obtained according to the scale "Predisposition to aggression and violence" ( $\mathrm{M}=$ 10.24 among women and $\mathrm{M}=9.13$ among men). According to these scales there were no statistically significant differences between male and female samples.

Only one indicator among men of natural science turned out to be higher, "Proneness to Addictive Behavior" ( $p<.01)$, which speaks about inclinations to the illusory-compensatory method of solving personal problems.

According to two scales, among women studying the disciplines of natural-scientific fields, assessments were higher than among men. Women had "Proneness to copability norms and rules" (p.01), "Predisposition to delinquent behavior" (p.01).

These estimates are indicative of disposition to oppose their own norms and values to the group ones, of the tendency to "trouble", and of the presence of delinquent tendencies in the subjects.

Table 4. Proneness of the Subjects to Deviant Behavior among Women and Men Pursuing the Disciplines of Natural Science

\begin{tabular}{|c|c|c|c|c|c|c|}
\hline \multirow[t]{2}{*}{ Subjects } & \multicolumn{2}{|c|}{$\begin{array}{l}\text { MenNS } \\
(\mathrm{n}=36)\end{array}$} & \multicolumn{2}{|c|}{$\begin{array}{l}\text { WomenNS } \\
\qquad(\mathrm{n}=50)\end{array}$} & \multirow[t]{2}{*}{$t(86)$} & \multirow[t]{2}{*}{$\mathrm{p}$} \\
\hline & $\mathrm{M}$ & SD & $\mathrm{M}$ & SD & & \\
\hline \multicolumn{7}{|l|}{ Scales } \\
\hline $\begin{array}{l}\text { Proneness to copability of norms and } \\
\text { rules }\end{array}$ & 6,44 & 2,65 & 8,06 & 2,19 & 3,08 & $\mathrm{p}<.01$ \\
\hline Proneness to addictive behavior & 8,13 & 3,69 & 6,18 & 2,63 & 2,87 & $\mathrm{p}<.01$ \\
\hline $\begin{array}{l}\text { Predisposition to self-mutilation and self- } \\
\text { distruction }\end{array}$ & 7,52 & 3,76 & 7,74 & 3,34 & 275 & ,784 \\
\hline $\begin{array}{l}\text { Predisposition to aggression and } \\
\text { violence }\end{array}$ & 9,13 & 3,86 & 10,24 & 3,39 & 1,40 & .165 \\
\hline
\end{tabular}




\begin{tabular}{|l|c|c|c|c|c|c|}
\hline Volitional control of emotional reactions & 6,69 & 2,86 & 7,42 & 2,16 & 1,33 &, 185 \\
\hline Disposition to delinquent behavior & 6,22 & 3,47 & 8,06 & 2,69 & 2,76 & $\mathrm{p}<.01$ \\
\hline
\end{tabular}

in the sample of men studying the humanities and natural science, the differences between men of the two fields are only according the scale
"Predisposition to self-damaging mutilation and self-destruction".

Table 5. Proneness of the Subjects to Deviant Behavior among Men Pursuing Natural-Science and Humanities

\begin{tabular}{|c|c|c|c|c|c|c|}
\hline & \multicolumn{2}{|c|}{$\begin{array}{l}\text { Men H } \\
(n=24)\end{array}$} & \multicolumn{2}{|c|}{$\begin{array}{l}\text { MenS } \\
(\mathrm{n}=36)\end{array}$} & \multirow[t]{2}{*}{$\mathrm{t}(60)$} & \multirow[t]{2}{*}{$\mathrm{p}$} \\
\hline & $\mathrm{M}$ & SD & $\mathrm{M}$ & SD & & \\
\hline \multicolumn{7}{|l|}{ Scales } \\
\hline $\begin{array}{l}\text { Proneness to copability of norms and } \\
\text { rules }\end{array}$ & 7,25 & 3,02 & 6,44 & 2,65 & 1,08 & ,281 \\
\hline Proneness to addictive behavior & 9,66 & 4,68 & 8,13 & 3,69 & 1,40 & , 165 \\
\hline $\begin{array}{l}\text { Predisposition to self-mutilation and self- } \\
\text { distruction }\end{array}$ & 9,62 & 3,64 & 7,52 & 3,76 & 2,13 & $\mathrm{p}<.05$ \\
\hline $\begin{array}{l}\text { Predisposition to aggression and } \\
\text { violence }\end{array}$ & 9,91 & 4,30 & 9,13 & 3,86 & ,730 & ,468 \\
\hline Volitional control of emotional reactions & 6,66 & 3,03 & 6,69 & 2,86 &,- 036 & ,971 \\
\hline Disposition to delinquent behavior & 7,00 & 3,71 & 6,22 & 3,47 & ,826 & ,412 \\
\hline
\end{tabular}

In the analyzed sample of women in the humanities and natural sciences, the highest average scores were found on the scale "Predisposition to aggression and violence" $(\mathrm{M}=10.29$ for women specializing in the human sciences, $\mathrm{M}=10.24$ for women of natural science). However, there were no statistically significant differences according to any of the scales.

Table 6. Proneness of the Subjects to Deviant Behavior among Women Pursuing Natural-Science and Humanities

\begin{tabular}{|c|c|c|c|c|c|c|}
\hline & \multicolumn{2}{|c|}{$\begin{array}{l}\text { Women H } \\
(\mathrm{n}=199)\end{array}$} & \multicolumn{2}{|c|}{$\begin{array}{l}\text { Women S } \\
(\mathrm{n}=50)\end{array}$} & \multirow[t]{2}{*}{$\mathrm{t}(249)$} & \multirow[t]{2}{*}{$\mathrm{p}$} \\
\hline & $\mathrm{M}$ & SD & $\mathrm{M}$ & SD & & \\
\hline \multicolumn{7}{|l|}{ Scales } \\
\hline $\begin{array}{l}\text { Proneness to copability of norms and } \\
\text { rules }\end{array}$ & 7,76 & 2,05 & 8,06 & 2,19 &,- 898 & ,370 \\
\hline Proneness to addictive behavior & 6,67 & 3,10 & 6,18 & 2,63 & 1,03 & ,301 \\
\hline $\begin{array}{l}\text { Predisposition to self-mutilation and self- } \\
\text { distruction }\end{array}$ & 8,02 & 3,77 & 7,74 & 3,34 & ,487 & ,626 \\
\hline $\begin{array}{l}\text { Predisposition to aggression and } \\
\text { violence }\end{array}$ & 10,29 & 3,15 & 10,24 & 3,39 & , 102 & ,919 \\
\hline Volitional control of emotional reactions & 7,38 & 2,19 & 7,42 & 2,16 &,- 095 & ,924 \\
\hline Disposition to delinquent behavior & 8,36 & 3,00 & 8,06 & 2,69 & 661 & ,509 \\
\hline
\end{tabular}




\section{Discussion}

It was revealed in the studies of many authors that men show aggression much more often than women, however some researchers refute this fact. So, Tieger in his work writes that there are no differences between boys and girls under 6 years old, and that the subsequent differences are determined by role education [13]. A. Frodi and J. Macallay [14] argue the opinion of the greater aggressiveness of men to be incorrect. They write that women are more anxious, more likely to feel guilty, suppress an open manifestation of aggression where men show it. In fact, women are no less prone to aggression if they think they are doing the right thing or feel free from responsibility $[15,16]$ In our study, the women studying the humanities and the natural science have the highest average scores on the scale "Predisposition to aggression and violence". It was also revealed that the inclination to aggression prevails among the students (men and women) of the humanities.

It was found in the work by Zubareva L.V. and Ptitsina N.A., as a result of the study, that women tend to addictive behavior to a much lesser extent than men, which is confirmed by our research[17,18].Men studying boththehumanitiesandnaturalsciences have theindicatorhigheraccording tothescale"Proneness toaddictivebehavior". This testifies to the predisposition of men to escape from reality by changing their mental state, their pronenessto illusory-compensatory ways of solving personal problems.

The humanities degree men proved to have higher indicator in "Predisposition to self-mutilation and self-destruction", which is evidence of the low value of their own life, the propensity to risk, the pronounced need for thrill. Women have a low level of social control. Natural sciences women have "Proneness to copability of norms and rules", "Predisposition to delinquent behavior". Men studying humanitarian disciplines are more prone to risk, need thrills [19].

\section{Conclusion}

Thus, as a result of our study it was revealed that there is no significant difference between the propensities to violate the norms among the students of the same sex of different specialties. The difference is that men of the humanities, in contrast to men of natural science, are more prone to risk, they have need for "extreme", thrill.

Comparing men and women studying humanitarian subjects, it is revealed that women are inclined to conflict with the generally accepted lifestyle and legal norms. Men have a tendency to an illusorycompensatory solution of personal problems, except that they are prone to various kinds of addictions. Theseare chemical addiction, eating disorders (overeating, starvation, rejection of food), and gambling (game dependency) and religiousdestructive behavior (religious fanaticism, involvement in the sect).

It should be noted that the same proneness to escape from reality through a change in one's mental state is inherent in men of natural sciences. Women of this subject area tend to break calm, seek difficulties that could later be overcome, are also inclined to violate generally accepted norms and rules.

\section{Acknowledgements}

The work is performed according to the Russian Government Program of Competitive Growth of Kazan Federal University.

The research was carried out with the support of the Russian Foundation for Basic Research and the Government of the Republic of Tatarstan within the framework of the research project № 17-16-16004 "Prognostic competence of younger schoolchildren with disabilities in the prevention of deviations"

\section{Disclosure Statement}

No potential conflict of interest was reported by the authors.

Corresponding author -Tatiana Artemyeva Tatyana.Artemeva@kpfu.ru

\section{References}

[1] Gilinsky, Y. I. (1993). Sociology of Diviant Behavior. $272 \mathrm{p}$.

[2] Rozhkov, M.I. (2001). Education of a Difficult Child: Children with Deviant Behavior: Study Guide - M.: VLADOS. 240 p.

[3] Kovalev, V.V. (1989).Pathology of Personality and Deviant Behavior: Manual on Psychiatry. M.: Nauka. 462 p.

[4] Zmanovskaya, E.V. (2003). Deviantology (Psychology of Deviant Behavior). M.: The Publishing Center "Akademiya". 288 p.

[5] Dimov, V. M.(1997). The Problems of Deviant Behavior of the Russian Youth (Sociological Aspect). The Journal of Moscow University. Series 18. Sociology and Politology. № 3. P. 45-55

[6] Chan, H.C., Beauregard, E. (2016). NonHomicidal and Homicidal Sexual Offenders: Prevalence of Maladaptive Personality Traits and Paraphilic Behaviors. Journal of interpersonal violence.31(13), $2259 \quad-\quad 2290 . \quad$ DOI 10.1177/0886260515575606

[7] Savina, N.N. (2009). The Factors of Defense and the Factors of Risk of Delinquent Adolescents. The Journal of Tomsk State Pedagogical University. № 4 (82). P. 91-93. 
[8] Baier, D., Kunkel, F. (2016). Effects of Physical and Psychological Bullying on Well-Being and Deviant Behavior of Adolescents. Psychologie in erziehung und unterricht. 63 (2), 137 - 150. DOI 10.2378/peu2016.art09d

[9] Twine, C.\&Botha, J. (2016). Male on-campus resident students' social normative behaviour: Influences on lived social climate by same gender beginning-year university students. Journal of psychology in Africa. 26 (5), 463-469. DOI 10.1080/14330237.2016.1229981

[10] Lopez, M.H., Felix, E.M., Ruiz, R.O.,Ortiz, O.G. (2016). Influence of social motivation, selfperception of social efficacy and normative adjustment in the peer setting. Psicothema. 28 (1), 32 - 39. DOI 10.7334/psicothema2015.135

[11] Aleksandrovich, R.A., Rean A. (2015). Family, social attitudes and anti-social behavior of children and teenagers. Rossiyskiy psikhologicheskiy zhurnal.12(1), 29. [in Russian]

[12] Herndon, J.S., Bembenutty, H. (2014). Inschool and social factors influencing learning among students enrolled in a disciplinary alternative school. Learning and individual differences.35, 49-55. DOI 10.1016/j.lindif.2014.07.007

[13] Tieger, T. (1980). On the biological basis of sex differences in aggression. ChildDevelopment. V. 51.P. 943-963
[14] Il'in,E.P. (2003). Differential Psychophisiology of Manand Woman. SP: Peter. 544 p.

[15] Sheeran, P., Harris, P.R., \&Epton, T. (2014). Does heightening risk appraisals change people's intentions and behavior? A meta-analysis of experimental studies. Psychological Bulletin. 140. 511-543.

[16] Killen, M., Rutland, A., Abrams, D., Mulvey, K. L., \&Hitti, A. (2013). Development of intra - and intergroup judgments in the context of moral and social-conventional norms. Child Development. Vol $84 . \quad$ 1063-1080. URL: http://onlinelibrary.wiley.com/doi/10.1111/cdev.12 $\underline{011 / \text { references;jsessionid=4C4FF2B69487273DA7 }}$ 07C0C715DB4870.f03t04?globalMessage $=0$

[17] Ptitsina, N. A., Zubaryeva L. V. (2010). Gender Aspects of Addictive Behavior in Student Environment. Woman in Russian Society. № 2.P. 80-92.

[18] Nigmatullina, I.A., Artemyeva, T.V. (2015). Integration of Educational and Research Activity of the Federal University Students, Studying in the Approach «Special (Speech Pathology) Education». The Social Sciences. 10(2). 76-80.

[19] Platow M. J., Grace D. M., Wilson N., Burton D., Wilson A. (2008).Psychological group memberships as outcomes of resource distributions. European Journal of Social Psychology. Chichester: T. 38. Iss. 5. P. 836-851 